\title{
PENINGKATAN KETERAMPILAN MENULIS PARAGRAF MELALUI PENERAPAN KEGIATAN MENULIS JURNAL DAN PEMANFAATANYA UNTUK PENILAIAN AUTENTIK PADA SISWA KELAS VIII SMP NEGERI 2 BATUKLIANG KABUPATEN LOMBOK TENGAH
}

\section{Iri Murti \\ SMP NEGERI 2 BATUKLIANG}

\begin{abstract}
Abstrak. Salah satu persoalan yang ditemukan di sekolah adalah rendahnya keterampilan menulis siswa, khususnya keterampilan menulis paragraf. Hal tersebut terjadi karena strategi pembelajaran menulis yang digunakan belum memberi kesempatan lebih banyak pada siswa untuk mengemukakan gagasan secara tertulis dengan lebih bebas, ekspresif, dan spontan. Pembelajaran menulis yang dilakukan belum mendorong terbentuknya kebiasaan menulis pada siswa. Di sisi lain, penilaian pembelajaran menulis yang diterapkan juga belum dapat memberi informasi yang sebenarnya tentang perkembangan keterampilan menulis siswa. Untuk mengatasi hal tersebut, diterapkan kegiatan menulis jurnal pada siswa dan memanfaatkan tulisan dalam jurnal itu untuk bahan penilaian autentik. Dalam penerapannya kegiatan menulis jurnal tersebut dilakukan dalam tiga tahapan. Kegiatan tahapan itu adalah (1) pemahaman konsep dan pemodelan kegiatan menulis jurnal, (2) pelaksanaan dan pembiasaan menulis jurnal, dan (3) penilaian autentik dengan memanfaatkan tulisan dalam jurnal siswa. Pendekatan yang digunakan dalam penelitian ini adalah pendekatan kualitatif, sedangkan rancangan penelitian yang digunakan adalah penelitian tindakan kelas. Rancangan penelitian tindakan kelas tersebut dilakukan dalam tiga siklus penelitian. Subjek penelitiannya adalah siswa kelas VIII A SMPN 2 Batukliang. Hasil penelitian menunjukkan bahwa kegiatan tersebut dapat meningkatkan keterampilan menulis paragraf siswa, baik dari segi kuantitas maupun kualitas paragraf yang dihasilkan. Kegiatan menulis jurnal juga membuat kegiaan menulis menjadi lebih menarik dan bermakna bagi siswa. Peningkatan tersebut tidak terlepas dari upaya guru memberi respon, mengembangkan dialog, memodelkan cara menulis paragraf yang benar, mencermati kesalahan yang kerap dilakukan siswa, membiasakan secara tetap, serta memberikan berbagai arahan untuk membangkitan kreativitas siswa dalam menulis paragraf. Bimbingan dan arahan guru itu tetap diberikan, meskipun menulis jurnal adalah kegiatan menulis yang bersifat informal. Berdasarkan pembahasan hasil penelitian disarankan kepada guru bahasa Indonesia sebaiknya kegiatan pembiasaan menulis jurnal terus diterapkan dan dilakukan dengan disertai bimbingan yang intensif dan terarah. Dengan mencermati isi tulisan siswa, disarankan pula kepada guru mata pelajaran lain sebaiknya kegiatan menulis jurnal ini dapat diterapkan karena selain melatih keterampilan menulis paragraf, jurnal juga dapat mengkomunikasikan serta merefleksikan hasil belajar dan perkembangan pribadi siswa.
\end{abstract}

Kata Kunci : menulis paragraf, menulis jurnal, penilaian autentik 


\section{PENDAHULUAN}

Pembelajaran bahasa Indonesia secara fungsional dan komunikatif adalah pembelajaran yang lebih menekankan siswa untuk belaajar berbahasa, dalam kaitannya dengan fungsi bahasa sebagai alat untuk berkomunikasi. Siswa bukan sekedar belajar tentang pengetahuan bahasa, melainkan belajar menggunakan bahasa untuk keperluan berkomunikasi. Untuk itu, pendekatan pembelajaran yang sesuai adalah pendekatan komunikatif.

Pembelajaran bahasa Indonesia dengan pendekatan komunikatif itu diarahkan untuk membentuk kompetensi komunikatif, yakni kompetensi kemampuan untuk menggunakan bahasa Indonesia sebagai alat komunikasi, baik pada aspek pemahaman, aspek penggunaan, maupun aspek apresiasi (Suparno 2001). Hal tersebut diatas berarti, melalui pembelajaran bahasa Indonesia diharapkan siswa memiliki kemampuan untuk menangkap makna dari sebuah pesan atau informasi yang disampaikan serta memiliki kemampuan untuk menalar dan mengemukakan kembali pesan atau informasi yang diterimanya itu. Siswa juga diharapkan memiliki kemampuan untuk mengekpresikan berbagai pikiran, gagasan, pendapat, dan perasaan dengan menggunakan bahasa yang baik. Kompetensi komunikatif itu dapat dicapai melalui proses pemahiran yang dilatihkan dan dialami dalam kegiatan pembelajaran.

Salah satu aspek keterampilan berbahasa yang berkaitan dengan pengungkapan pikiran, gagasan, pendapat, dan perasaan tersebut adalah keterampilan menulis paragraf. Keterampilan menulis paragraf sebagai keterampilan berbagasa yang bersifat produktif-aktif merupakan salah satu kompetensi dasar berbahasa yang harus dimiliki siswa agar terampil berkomunikasi secara tertulis. Siswa akan terampil mengorganisasikan gagasan dengan runtut, menggunakan kosakata yang tepat dan sesuai, memperhatikan ejaan dan tanda baca yang benar, serta menggunakan ragam kalimat yang variatif dalam menulis jika memiliki kompetensi menulis paragraf yang baik.

Berdasarkan pengalaman dan pengamatan di kelas, ditemukan bahwa menulis kerap kali menjadi suatu hal yang kurang diminati dan kurang mendapat respon yang baik dari siswa. Siswa tampak mengalami kesulitan ketika harus menulis. Siswa tidak tahu apa yang harus dilakukan ketika pembelajaran menulis dimulai. Mereka terkadang sulit sekali menemukan kalimat pertama untuk memulai paragraf. Siswa kerap menghadapi sindrom kertas kosong (blank page syndrome) tidak tahu apa yang akan ditulisnya. Mereka takut salah, takut berbeda dengan apa yang diinstruksikan gurunya.

\section{KAJIAN TEORI}

\section{Kegiatan Menulis Jurnal sebagai Alternatif Tindakan}

Salah satu cara alternatif yang dapat diterapkan untuk membiasakan dan melatihkan keterampilan menulis pada siswa, khususnva menuiis paragraf adalah dengan menuiis jurnal atau dalam istilah yang lebih umum dikenal dengan menulis buku harian. Pembiasaan dan rutinitas menulis tersebut akan menjadi suatu kebiasaan perilaku yang positif. Dengan menulis jurnal. siswa dapat berlatih menulis lebih sering dan lebih bebas di luar jam pembelajaran menulis secara khusus. Siswa akan terbiasa mengungkapkan gagasan atau perasaannya secara tertulis dalam bentuk paragraf-paragraf yang baik. Jurnal dapat menjadi sarana yang membantu siswa untuk belajar menulis dengan lebih menyenangkan dan berhasil (Eanes, 1997:457).

Kegiatan menulis jurnal itu tidak hanya dilakukan ketika pmbelajaran menulis, pada pembelajaran bahasa Indonesia dengan fokus keterampilan lain kegiatan tersebut juga dapat disisipkan. Guru dapat menyediakan waktu setiap bari atau beberapa hari dalam seminggu sekitar sepuluh sampai dengan lima bela menit bagi siswa untuk menuiis jurnal pribadinva (Capacchione, 1989:15; Tompkins \& Hoskisson, 1991:189). Dalam konteks sistem pembelajaran sekolah di Indonesia sekilas 
terkesan penyedian waktu ini mengurangi alokasi waktu pembelajaran pokok, tetapi bila disadari lebih jauh pengurangan alokasi waktu pembelajaran ini, yang dimanfaatkan untuk menulis jurnal, dapat memberi manfaat yang besar bagi siswa.

\subsection{Pemanfaatan Kegiatan Menulis Jurnal sebagai Bahan Penilaian Autentik}

Tulisan siswa dalam jurnal dapat digunakan sebagai salah satu bahan untuk penerapan penilaian autentik. Penilaian autentik yang memanfaatkan tulisan siswa dalam jurnalnya memberikan gambaran yang sebenarnya (autentik) tentang performansi keterampilan menulis paragraf siswa. Penilaian ketcrampilan menulis tersebul bersifat kompleks dan berkelanjutan.

Realisasi penerapan penilaian autentik dengan memanfaatkan jurnal berguna untuk memberi informasi tentang perkembangan kosakata, struktur kalimat, kelancaran dan kepaduan penataan gagasan dalam paragraf; serta penggunaan aspekaspek mekanik yang diperoleh siswa setahap demi setahap. Jurnal rnenjadi sebuah portofolio yang memberikan data tentang perkembangan keterampifan menulis siswa secara menyeluruh. Selain itu. berbagai kekurangan dan kesalahan yang terdapat tulisan siswa melalui penilaian autentik dapat dibenahi dan dapat menjadi pertimbangan perencananaan pembelajaran selanjutnva sehingga konsep penilaian yang' sesungguhnya terlaksana.

Salah satu model atau perangkat penilaian autentik dalam pembelajaran keterampilan menulis yang dapat dilakukan adalah memanfaatkan tulisan dalam jurnal siswa. Jurnal dapat menjadi sebuah afternatif bahan penilaian yang efektif untuk mengetahui dan melihat perkembangan keterampilan menulis siswa. Jurnal siswa dapat menjadi bagian dari portofoiio yang merekam perkembangan menulis dari waktu ke waktu. Selain itu, pemanfaatan jurnal dalam penilaian menjadikan penilaian tidak hanya dilakukan guru, tetapi siswa juga dapat dilatih untuk melakukan penilaian diri-sendiri (self- assesment) terhadap tulisan-tulisan yang telah dibuatnya. Siswa juga dapat memilih sebuah tulisan andalan dalam jurnal yang ditulisnya untuk dinilai atau ditanggapi oleh temannva (peer-assesment). Bahkan bila siswa tidak keberatan, orangtuanya pun dapat membaca dan memberikan penilaian terhadap tulisantulisan dalam jurnal itu.

Melalui kegiatan ini siswa dapat berpikir kritis, mengamati, menemukan kesaiahannya sendiri kemudian berupava membuat tulisan yang lebih baik. Bila kegiatan ini dapat dilakukan secara efektif dan optimal, maka diharapkan keterampilan menulis siswa, khususnya keterampilan menulis paragraf dapat meningkat. Proses penilaian dan pembelajaran menulis pun menjadi lebih bermakna hagi siswa.

\section{METODE PENELITIAN ।}

\section{Pendekatan dan Raneangan Penelitian}

Pendekatan yang digunakan dalan penelitian ini adalah pendekatan kualitatif Penggunaan pendekatan kualitatif ini didasari pemikiran bahwa penelitian ini berupaya untuk mengungkapkan berbagai gejala yang memberikan makna dan informasi scsuai konteks dan tujuan penelitian melalui pengumpulan data. Pengumpulan data tersebut dilakukan pada latar alamiah dengan peneliti sebagai instrumen utama dalam pengumpulan data.

Sejalan dengan pemfokusan dan latar alaminya yang berwujud aktivitas di dalam kelas, rancangan penelitian tindakan yang diterapkan adalah penelitian tindakan kelas classroom action reserch).

Berdasarkan pendekatan dan rancangan PTK yang akan diterapkan, prosedur dan langkah-langkah penelitian ini mengikuti prinsip-prinsip dasar penelitian tindakan. Oleh karena itu, model rancangan penelitian tindakan kelas yang akan digunakan adalah model spirail-bersiklus sebagaimana dikemukakan Lewin dan dikembangkan oleh kemmis dan Elliot (Elliot, 1991:71). Secara umum model siklus ini meliputi (1) perencanaan, (2) 
pelaksanaan tindakan, (3) pengamatan, (4) analisis dan refleksi.

\section{Subjek Penelitian}

Subjek penelitian ini adalah siswa kelas VIII A SMP Negeri 2 Batukliang. Seluruh siswa akan dikenai tindakan karena penelitian tindakan kelas adalah penelitian yang mengikuti alur pembelajaran sebenarnva. Pertimbangan pemilihan kelas II sebagai sumber data penelitian karena kelas VIII A merupakan kelas peneliti dalam melaksanakan tugas sehari-hari dan di kelas ini terdapat masalah tersebut. Selain itu, kelas VIII SMP merupakan kelas tengah, dengan siswa yang telah dapat herpikir secara logis dan abstrak serta telah mempunvai dasar pengetahuan awal tentang keterampilan menulis yang dipelajari di kelas VII. Pengetahuan awal tersebut, misalnya bentuk paragraf, pola-pola kalimat, dan penggunaan ejaan atau pungtuasi.

\section{Data dan Teknik Pengumpulan Data}

Data yang ingin diperoleh adalah data tentang proses kegiatan dan data tentang hasil kegiatan menulis jurnal. Data-data itu meliputi (1) data awal tentang kemampuan kcterampilan menulis paragraf siswa (2) data pokok tentang upaya peningkatan keterampilan menulis paragraf melalui tindakan pemahaman konsep dan pemodelan kegiatan menulis jurnal. (3) data pokok tentang upaya peningkatan keterampilan menulis paragraf melalui tindakan pelaksanaan dan pembiasaan kegiatan menulis jurna1, (4) data pokok tentang upaya peningkatan keterampilan menulis paragraf melalui tindakan penilaian autentik dengan memanfaatkan tutisantulisan dalam jurnal siswa, serta (S) data pendukung tentang perkembangan keterampilan menulis siswa setelah tindakan. Untuk memperoleh data penelitian, teknik pengumpulan data yang akan digunakan adalah wawancara, pengamatan, pendokumentasian. dan pemberian tes menulis. Sesuai dengan (karakteristik penelitian kualitatif, dalam penelitian ini peneliti berperan sebagai instrumen utama pengumpulan data. Data-data tersebut berupa transkrip wawancara dan rekaman kegiatan belajar, catatan lapangan dokumentasi hasil tulisan siswa dan hasil tes Menulis.

\section{Analisis Data}

Analisis data dalam penelitian ini akan dilakukan dengan dasar analisis data model alir yang terdiri atas tiga tahapan yaitu (1) mereduksi data, (2) menyajikan data, dan (3) menarik kesimpulan dan memverifikasi. Analisis data tersebut dilakukan selama dan sesudah penelitian, mulai dari tahap perencanaan kegiatan, pelaksanaan. Hingga refleksi kegnatan.

\section{HASIL PENELITIAN DAN PEMBAHASAN \\ Perencanaan Tindakan}

Pelaksanaan setiap siklus terdiri atas tiga tindakan pokok. Adapun ketiga tindakan pokok tersebut adalah (1 ) pemahaman dan pemodelan. (2) Pelaksanaan dan pembiasaan kegiatan menulis jurnal, dan (3\} pelaksanaan penilaian autentik melalui jurnal. Dalam tiap siklus, tindakan pertama dilaksanakan dengan alokasi waktu dua kali pertemuan jam pelajaran. Tindakan kedua dilakukan terinteigrasi dalam tiap jam pelajaran bahasa Indonesia selama empat kali pertemuan, guru menyediakan waktu sepuluh sampai dengan lima belas menit di menit awal atau di akhir pelajaran untuk menulis. Materi tulisan jurnal disesuaikan dengan konteks materi pembelajaran saat itu. Tindakan ketiga selain dilakukan secara bersinambungan oleh yang, dilakukan pula oleh siswa sekitar dua puluh menit pada waktu yang ditentukan. Setiap siklus siswa menulis jurnal sebanvak lima kali. Tindakan-tindakan pokok tersebut langkahlangkahnya tergambar dalam tabel 1 berikut ini.

Tabel 1. Rencana Pembelajaran dalam Pelaksanaan Tindakan 

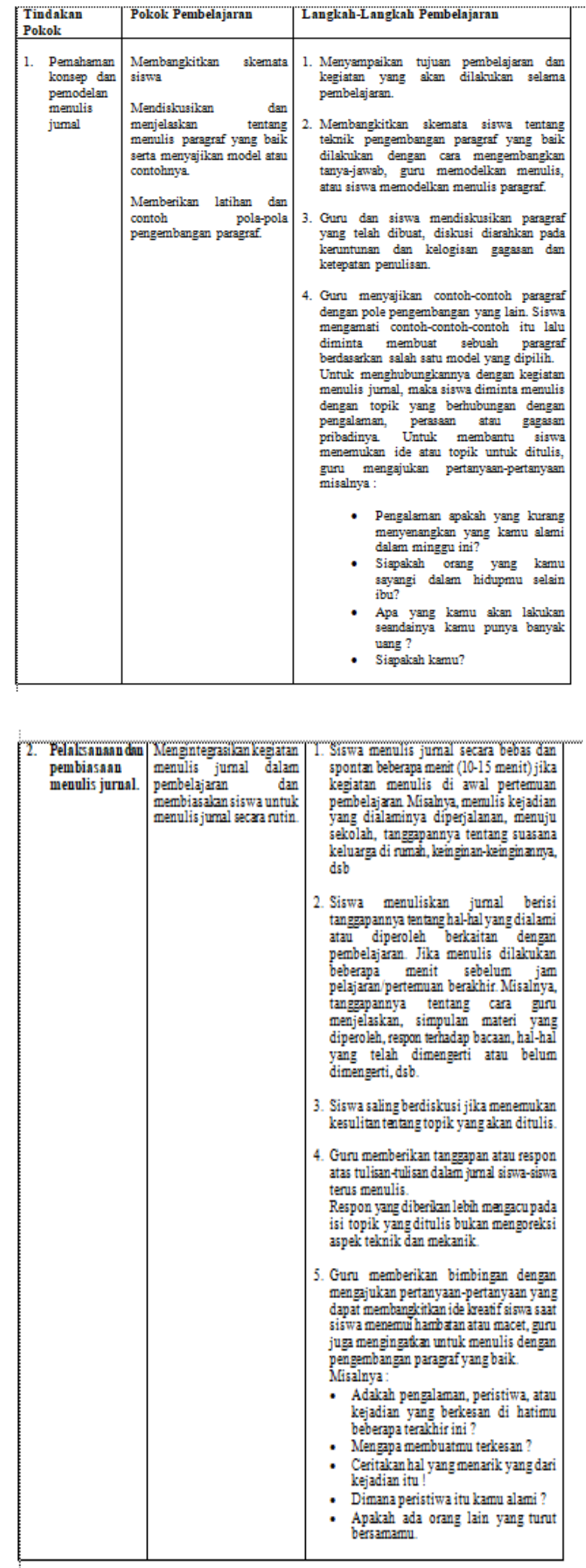

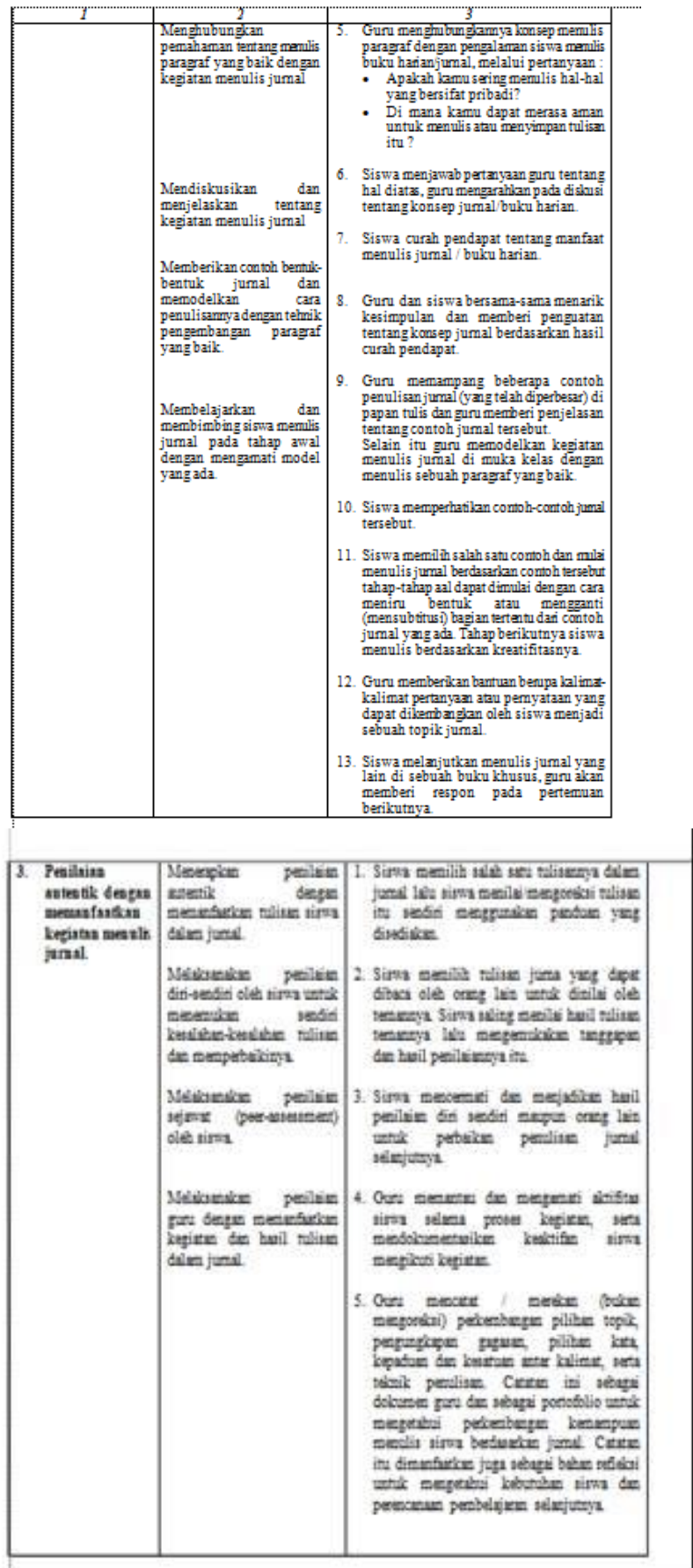

\section{Pelaksanaan Tindakan}

Penelitian dilakukan dalam tiga siklus. Setiap siklus terdiri dari kegiatan perencanaan, pengamatan, analisis temuan, dan refleksi tindakan. Dalam tiap siklusnya dilakukan tiga pokok pembelajaran. Ketiga pokok pembelajaran itu adalah (1) kegiatan pemahaman konsep dan pemodelan kegiatan menulis jurnal, (2) pelaksanaan dan pembiasan 
menulis jurnal, dan (3) penilaian autentik dengan memanfaatkan tulisan dalam jurnal siswa.

\section{Pemahaman Konsep dan Pemodelan Kegiatan Menulis}

Dalam kegiatan peanahaman konsep dan permodelan ini guru melakukan langkahlangkah pokok dalam pembeiajaran. langkahlangkah tersebut, yaitu (1) menyampaikan tujuan dan pokok-pokok kegiatan pembelajaran. (2 ) membangkitkan skemata siswa. (3) menjelaskan dan mendiskusikan tentang mcnulis paragraf yang baik, (4) memberikan latihan dan contoh penulisan paragraf yang baik, (5) menghubungkan kegiatan menulis paragraf dengan menulis jurnal, (6) mendiskusikan dan menjelaskan tentang kegiatan menulis jurnal. memajankan contoh-contoh jurnal sebagai model serta (8) menulis jurnal tahap awal dengan mengamati model yang disajikan. Melalui kegiatan-kegiaian itu, sisa manipu mengkontruksi sendiri konsep penngetahuannya tentang menulis paragraf dengan pola pengembangan yang baik.

Untuk lebih mengektifkan proses pembelajaran guru memanfaatkan media pembelajaran. Media digunakan berupa (1) lembar bagan struktur paragraf, (2) contohcontoh, tulisan yang, dikutip dari jurnal siswa, dan (3) gambar-gambar tentang berbagai peristiwa aktual yang tengah terjadi.

\section{Pelaksanaan dan Pembiasaan Menulis Jurnal}

Pada siklus II langkah-langkah pembalajaran tersebut tetap sama, tetapi lebih bervariasi dibanding langkah-langkah pembelajaran pada siklus I. Pada pertemuan pertama, guru meminta Siswa untuk menulis tentang kegiatan kesehariannya, perasaan, pengalaman yang dialaminya, gagasan, atau tanggapannya tentang sesuatu. Pada pertemuan kedua, guru memancing gagasan siswa untuk menulis dengan berandai-andai melalui kegiatan tanya-jawab. Hal tersebut dapat dilihat pada transkrip rekaman dialog berikut :
Guru : "Kalau boleh Bapak ingin bertanya pada Riza. apakah citacitamu?"

$\begin{array}{llll}\text { Siswa } & : & \text { "Jadi dokter. Pak } & \\ \text { Guru } & : & \text { "Kalau kamu, Nur?" } & \\ \text { Siswa } & : \quad \text { "Saya ingin jadi guru saja, } \\ & \text { Pak?" } & & \\ \text { Guru } & : \quad \text { "Seandainya cita-cita kalian } \\ & \text { berdua tercapai apa yang kalian } \\ & \text { lakukan?" }\end{array}$

Siswa : "Menolong orang sakit yang tidak mampu, Pak?

Siswa : "Menjadi guru yang disenangi muridnya."

Guru : : "Bagus, yang lain tentunya juga punya cita-cita yang bermacammacam. Kali ini Bapak ingin kalian menulis dalam jumai dengan topik "Seandainya aku...",

Misalnya, seandainya aku menjadi dokter, seandainya aku seorang guru, dan sebngainya."

Siswa : "Boleh Pak, kalau 'seandainya aku punya sayap'?"

Siswa : "Seandainya aku seorang jutawan, Pak."'

Guru : "Boleh saja, yang penting tulisan kalian runtut dan padu sehingga gagasan yang dikemukakan mudah dimengerti."

(CL-TR /PPMJ/K2/S2/Rabu,17-03-17)

Dalam dialog di atas tergambar keakraban guru dalam menjalin komunikasi dengan siswa. Komunikasi yang akrab tersebut dilakukan guru untuk memancing gagasan yang lebih kreatif untuk ditulis da1am jurnal. Sebelum menulis, guru menanyakan tentang harapan dan cita-cita siswa. Guru mengajak siswa berimajinasi seandainya cita-cita atau keinginan itu tercapai.

Guru kemudian menambahkan dan mrnuliskan beberapa topik yang dikemukakan siswa di papan tulis. Topik-topik tersebut, antara lain sebagai berikut :

1) Seandainya aku punya sayap.

2) Seandainya aku seorang jutawan. 
3) Seandainya aku menjadi Presiden di Negeri ini.

4) Seandainya aku menjadi anggota DPRI

5) Seandainya aku dapat berkeliling dunia.

6) Seandainya aku menjadi seekor serangga.

Siswa cukup tertarik dengan pilihan topik-topik tersebut. Setelah memilih salah satu topik kemudian siswa menulis jurnalnya penuh antusias. Berikut ini disajikan salah satu contoh hasil tulisan siswa. Tulisan RZA (Kelompok atas):

Aku sangat prihatin dan sedih melihat pertikaian, perpecahan dan kekerasan yang terjadi di negeri ini. Aku ingin sedarkan virus perdamaian di hati setiap rakyat di negeri ini agar mereka berhenti bertikai. Akan aku dudukkan semua orang yang bertikai di bawah atap kasih sayang negeriku. Kuajak mereka bergandeng tangan membangun negeri ini menjadi negeri yang damai dan sejahtera. Seтиa itu akan ku lakukan Seandainya aku menjadi presiden di negeri ini.

Aku akan menjadi pemimpin yang dapat menjadi teladan bagi rakyat. Keadiian dan kesejahteraan akan menjadi perjuanganku. Aku tidak ingin negeri ini terus terpuruk dalam hutang dan kemiskinan. Hal itu menjadi citacita. sayangnya aku cuma siswi SMP Moramo tak ada yang memilihku jadi presiden.

(HTS/PPMJ/K2/S2/KI-At -RZA)

Pada siklus ini langkah-langkah pembelajaran juga diperbaiki kembali berdasarkan hasil refleks siklus II. Pada kegiatan menulis pertama. siswa tetap akan diminta menulis bebas tentang hal-hal yang berkaitan dengan perasaan atau pengalamannya. Namun pada pertemuan kedua guru meeminta siswa menuliskan tanggapannya tentang proses pembejajaran yang diikutinya, sehingga kegiatan menulis jurnal dilakukan di pengujung jam pelajaran. Berikut ini disajikan salah satu contoh tulisan siswa terkait dengan hal tersehut.

Tulisan UMA (keloinpok tengah)

Rabu. 10 September 2018

Hari ini kami belajar tentang menuhs telegram. Menulis telegram ternyata repot, aku bingung. Banyak aturan yang harus diperhatikan dalam menulis. Katimatnya harus singkat padat, tanda titik dan koma di tulis dengan huruf. Tulisannya harus ditulis dengan huruf kapital atau huruf kecil seтиa.

Dulu pernah sekali aku mengirim telegram. Aku menulis berita yang ingin dikirim di selembar kertas yang disediakan petugas. Namun, aku ngga lagi memperhatikan aturanaturan itu, tetapi petugas tetap menerimanya dan ngga marah. Menurutku mengirim telegram juga sudah ngga praktis. Sekarang kan lebih keren mengirim berita lewat SMS. Sebaiknya. Pak Agus mengajarkan saja cara menulis SMS yang baik daripada tentang telegram yang jarang digunakan. (HTS/PPMJ/K3/S2/Kl-At-UMA)

Tulisan SNT (kelompok tengah). Rabu.

10 September 2018

Membuat telegram ternyata mudah. Berita yang panjang harus diringkas bila ingin dikirim telegramnya. Pelalaran hari ini membuatku tahu bahwa cara penulisan telegram menggunakan huruf kapital seтиa atau hurul kecil. Tanda-tanda baca juga harus ditulis huruf kapital seтиa.

Pak Nur rnengajarkan kami menulis telegrom dengan cara yang menarik. Kami tidak langsung dljelaskan tentang telegram, tetapi disuruh mencari sendiri dengan mencermati dan berdiskusi. Dengan begitu saya saya jadi cepat mengerti. Saya senang dengan cara ngajar beliau

Aku belum pernah mengirin telegram. Kalau aku ada kesempatan aku ingin mengirim telegram pada saudaraku di tempat lain. Akan aku terapkan pelajaran yang kudapat hari ini. Aku senang dengan pelajaran bahasa Indonesia hari ini.

(HTS/PPM/K3/S2/Kl-Tg-SNT)

Dua contoh tulisan di atas memberikan gamharan tentang tanggapan yang berbeda terhadap pelajaran yang diterima siswa hari itu. Tulisan pertama mengungkapkan kekurangsetujuanya terhadap materi pelajaran yang disajikan berkaitan dengan konteks penggunaannva. sedangkan paragraf kedua memperlihatkan hal yang, sebaliknya. Dengan 
cara yang berbeda, kedua tulisan tersebut memberi gambaran tentang apa yang mereka peroleh dalam kegiatan pembelajaran tulisan pertama yang menunjukkan bahwa bentuk paragraf argumentasi digunakan siswa dalain jurnalnya. Isi Kedua tulisan siswa dalam jurnal tersebut dapat menjadi refleksi guru dalam merencanakan pembelajaran selaniutnya.

Pada kegiatan ketiga, guru mengaitkan kegiatan menulis dengan peristiwa denuan peritiwa aktual yang terjadi. Pada kegiatan keempat kembali guru akan memberi kesempatan siswa mengekspresikan gagasannya secara bebas tentang pengalaman, perasaan. atau tanggapannya terhadap suatu hal. Dalam tiap siklus, pelaksanaan dan pembiasaan menulis jurnal dilaksanakan sebanyak empat kali. Tiap dua kali pertemuan menulis jurnal diselingi dengan kegiatan penilaian siswa. Selama siswa menulis, guru senantiasa memberikan bimbingan yang dapat membangkitkan keretivitas siswa dalam menulis.

Pemberian respon diberikan guru secar a tertulis, tetapi respon yang diberikan bukan hanya mengoreksi kesalahan siswa. Respon diberikan, mengarah pada tanggapan guru terhadap isi/hal yang dikemukakan siswa. Hal tersebut dapat diiihat pada contoh tulisan siswa berikut.

Kamis, 11 September 2018

Sudah lama aku tidak pulang ke Wawosunggu. Bosan Tinggal di pondok terus. Aku rindu sama adikku dan ibuku. Aku mau sekali pulang ketemu mereka. Kenapa oleh ayahku aku jauh-jauh di sekolahkan di sini? Jauh dari keluargaku padahal di dekat rumahku juga ada sekolah MTs.

Hari minggu kemarin aku ingin pulang tetapi uangku tidak cukup. Hari seninnya juga ada ulangan di sekolah. Akhirnya sore itu. setelah sholat magrib aku cepat-cepat tidur sampai lupa sholat Isya. Dalam tidurku aku akhirnya ketemu sama adik dan ibuku biar cuma hanya dalam mimpi.

Respon Guru :

Jurnal Pendidikan Mandala
Seandalnya hari Minggu kemarin kami pulang ke Wawosunggu. hari Senin kamu mungkin tidak ikut ulangan. Kamu tetap dapat bertemu dengan ibu dan adikmu walaupun hanya dalam mimpi, Semoga mimpimu dapat mengobati kerinduanmu.

HTS/PPMJ/K1-Bw-ASW)

Dalam contoh tulisan di atas tergambar bagaimana guru dalam memberi respon terhadan apa yang dikemukakan siswa. Respon ini menjadi rnembuat siswa senang karena guru menanggapi dan menunjukkan simpati terhadap persoalan yang dialaminya. Hal ini sangat mengacu motivasi untuk terus menulis. Siswa merasa tulisannya dibaca dan dihargai oleh guru mereka.

\section{Penilaian Autentik dengan Memanfaatkan} Tulisan dalam Jurnal Siswa

Dalam tiap siklus penilaian autentik tulisan Jurnal siswa dilakukan oleh Guru dan siswa. Penilaian Guru mencakup penilaian proses dan penilaian hasil yang dilakukan secara berkelanjutan selama tindakan. Kegiatan penilaian oleh siswa mencakup penilaian hasil tulisan yang dilakukan oleh diri sendiri dan rekan sejawat /antarsiswa.

Kegiatan penilaian oleh siswa akan dilakukan dua kali. Penilaian pertama. berupa penilaian diri seridiri dilakukan setelah kegiatan tertulis kesatu dan kedua. Penilaian tiang kedua berupa penilaian rekan sejawat dilakukan telah kegiatan menulis ketua dan keempat. Dalam penilaian sejawat siswa diminta untuk memilih salah satu tulisannya untuk saling dipertukarkan dan dinilai oleh temannya. Untuk rnembantu siswa me!akukan penilaian terhadap tu!isannya, guru menyediakan panduan penilaian. Selama siswa melakukan penilaian, guru akan senantiasa memberikan bimbingan pada siswa. Berikut ini disajikan salah satu contoh hasil penilaian terhadap tulisan temannya.

Waktu masih di kelas 6 SD, aku ingat kalau aku pernah ikut kegiatan memperingati hari kartini. Waktu itu aku disuruh memakai baju kebaya dan rambutku harus disanggul. Aku tidak punya baju kebaya kecil, akhirnya ibu mengecilkan salah satu baju kebayanya agar pas dengan 
badanku. Aku juga dimakeup dan dipasangi sanggul oleh ibu.

Hari itu aku diantar ayah ke sekolah naik matoku. Karena aku memakai kain sandal slopku waktu turun dari motor aku hampir jatuh., Kepalaku juga rasanya berat sekali karena dipasangi sanggul. Aku tidak berani banyak bergerak takut sanggulku jatuh. Jalannya pun harus pelan-pelan. Repot sekali rasanya memakai baju kebaya. $k u$.

Semua temanku yang lain juga memakai kebaya. Kami kemudian disuruh berbaris. lbu guru lalu menilai penampilan kami. Untunglah ketika diadakan penilaian busana aku berhasil meraih juara satu. Pengalamanku saat itu sungguh-sungguh berkesan bagiku.

Komentar: Tulisannya sudah bagus, aku kasih, tapi jangan lupa kalau ya! Kalau pakai "semua" kata "teman" satu saja. kata Kapital ya' Kalau pakai "sетиa" kata "teman"satu saja. Kata "karena" lebih bagus nggak di awal kalimat Perbaiki, ya (HTS/PAMJ/S3/KLAt-RZA)

Penilaian oleh guru dilakukan secara berkelanjutan dengan menilai kualitas paragraf yang dihasilkan siswa tiap pertemuan dan mencatat kesalahan-kesalahan yang kerap dilakukan siswa. Berikut ini disajikan salah satu contoh lembar catatan yang dibuat guru.

\section{Contoh Catatan Guru Tentang Kekerapan} Kesalahan dalam Tulisan Siswa

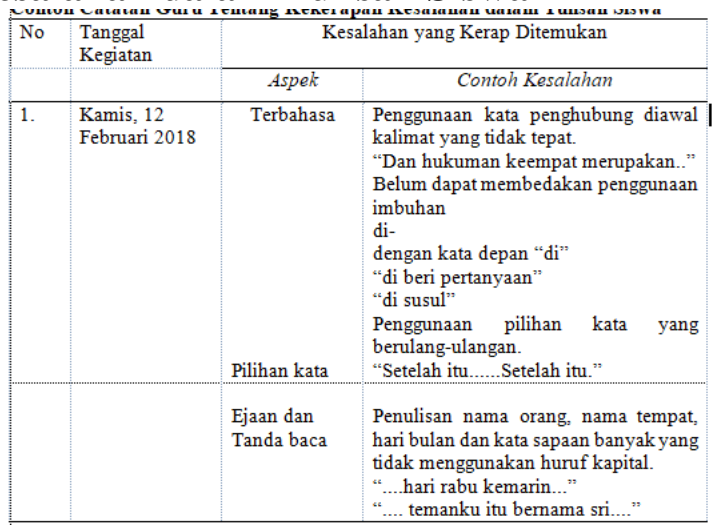

Catatan kekerapan kesalahan seperti daiatas selanjutnya menjadi acuan guru untuk perencanaan pembelajaran berikutnya. Guru membenahi kesalahan-kesalahan tersebut dengan mengintegrasikannya dalam kegiatankegiatan pembelajaran rutin. Dengan tidak mengoreksi langsung kesalahan pada tulisan siswa, guru memberikan kesempatan pada siswa untuk menemukan sendiri kesalahannya. Siswa juga merasa senang karena merasa tulisannya tidak selalu disalahkan oleh guru.

Hasil penilaian autentik ini juga menjadi laporan tentang perkembangan menulis siswa, khususnva menulis paragraf. Dan pencatatan dan analisis hasil tulisan setiap pertemuan diperoleh informasi tentang perkembangan keterampilan siswa selama mendapat tindakan. Hasil dukumentasi penilaian itu selanjutnva menjadi bahan pertimbangan perencanaan pembelajaran selanjutnya.

\section{Pembahasan Hasil Peningkatan} Kemampuan Menulis Paragraf Siswa

Hasil penelitaan tindakan ini menunjukkan bahwa dengan pembiasaan menulis jurnal secara berkelanjutan, siswa menjadi terbiasa menulis paragraf dan keterampilan menulis paragrafnya pun meningkat. Indikator peningkatan keterampiian menulis paragraf tersebut dapat dilihat dari tiga hal yaitu (1) kuantitas gagasan yang dihasilkan, (2) kualitas paragraf: dan i:cantus asan aktivitas dan motivasi siswa.

Peningkatan pertama terlihat dari jumlah gagasan dan pilihan topik. Jumlah gagasan yang ditulis bertambah banyak serta memperlihatkan cara pemalu yang beragam, tidak datemukan lagi paragraf yang hanya terdiri dari satu kalimat. Peningkatan tersebut teriadi pada tiap siklus tindakan. Hal tersebut secara lebih jelas dapat terlihat pada tabel 2 berikut :

Tabel 2. Perbandingan Rata-rata Jumlah Gagasan dalam Tulisan Siswa Tiap Siklus 


\begin{tabular}{|l|l|c|c|c|}
\hline \multirow{2}{*}{ SIKLUS } & \multicolumn{2}{|c|}{ PARAGRAF } & \multicolumn{2}{c|}{ KALIMAT } \\
\cline { 2 - 5 } & Jumlah & Rata-Rata & Jumlah & Rata-rata \\
\hline Siklus I & 97 & 10,4 & 431 & 47,8 \\
\hline Siklus II & 120 & 13,3 & 554 & 61,6 \\
\hline Siklus III & 132 & 14,7 & 606 & 67,3 \\
\hline
\end{tabular}

Kualitas paragraf yang dihasilkan memperlihatkan peningkatan. Peningkatan kualitas tersebut mencakup aspek pengembangan topik, pengorganissia gagasan, penggunaan pilihan kata, tata bahasa, serta ejaan dan tanda baca yang secara bertahap semakin baik. Secara lebih jelas, hal tersebut tergambar dalam tabel berikut :

\section{Tabel 3. Perbandingan Nilai Rata-Rata dan Kualifikasi Kualitas Tulisan Siswa Per siklus.}

\begin{tabular}{|c|c|c|c|c|c|}
\hline \multicolumn{2}{|c|}{ SIKLUS I } & \multicolumn{2}{c|}{ SIKLUS II } & \multicolumn{2}{c|}{ Siklus III } \\
\hline $\begin{array}{c}\text { Nilai } \\
\text { Rata-Rata }\end{array}$ & Kualifikasi & $\begin{array}{c}\text { Nilai Rata- } \\
\text { Rata }\end{array}$ & Kualifikasi & $\begin{array}{c}\text { Nilai Rata- } \\
\text { Rata }\end{array}$ & Kualifikasi \\
\hline 2,3 & Cukup & 3,1 & Baik & 3,4 & Baik \\
\hline
\end{tabular}

Dari tabel di atas dapat dijelaskan siklus

I kualitas paragraf siswa rata-rata berkualitas cukup, cukup maka pada siklus II dan III meningkat menjadi baik. Dengan kata lain, paragraf yang ditulis siswa umumnya telah memiliki gagasan utama dan gagasan pengembang yang jelas. Gagasan-gagasan itu dikembangkan secara logis dengan pengorganisasian yang baik. Struktur kalimat dan peralihan antar gagasan dalam paragraf sudah memperlihatkan keefektifan, hal tersebut teriihat dari sedikitnya kesalahan dalam penggunaan konjungsi. Kosa-kata yang digunakan juga cukup tepat dan dapat mewakiii gagasan yang dikemukakan. Beberapa kesalahan tata bahasa dari mekanik tulisan masih diketemukan, tetapi tidak banyak dan tidak sampai mengaburkan makna gagasan yang dikemukakan.

Seiain itu, jumlah pilihan topik tulisan yang dihasilkan, sangat beragam. Hal itu menunjukkan bahwa siswa bahwa siswa telah dapat menentukan berbagai bahan, gagasan yang dapat mereka tulis. Keragaman topik tersebut dapat dilihat pada tabel berikut.

\begin{tabular}{|c|l|l|l|}
\hline \multicolumn{4}{|c}{ Tabel 4. Topik-Topik Tulisan Siswa selama Pelaksanaan Tindakan Tindakan } \\
\hline No & Topik Tulisan & No & Topik Tulisan \\
\hline 1. & Kenangan Di SD & 17. & Pelajaran dari Buku Bacaanku \\
2. & Keluargaku & 18. & Ringkasan Isi Buku Bacaanku \\
3. & Orang-Orang Disekitarku & 19. & Yang menarik dari Buku Bacaanku \\
4. & Tidak Setuju Hukuman & 20. & Perjuangan Kartini \\
5. & Sahabat Lama & 21. & Pengalaman Hari Kartini \\
6. & Musim lama & 22. & Adikku Berkebaya \\
7. & Musim Jambu Mete & 23. & Memancing \\
8. & Hari Minggu Membosankan & 24. & Pelajaran Hari ini \\
9. & Hobbiku membaca & 25. & Diariku \\
10. & Pengalaman Mengesankan & 26. & Ulang Tahun Kakakku \\
11. & Aku sakit & 27. & Kesendirianku \\
12. & Kepergian Sahabatku & 28. & Kamarku \\
13. & Dihukum Bersama & 29. & Sakitnya Hatiku \\
14. & Hari Minggu Yang Sedih & 30. & Terlambat lagi \\
15. & Tipuan Hadiah & 31. & Disengat Lagi \\
16. & Pasrahku & 32. & Guruku Berubah \\
& & & \\
\hline & & & \\
\hline
\end{tabular}

Keantusiasan, aktivitas, dan motovasi siswa untuk menulis yang semakin meningkat. Hal itu ditandai dengan kemauan siswa membuat buram tulisannya di rumah, walaupun tanpa penugasan dari guru. Siswa cepat menulis di kelas karena umumnya mereka telah memiliki buram yang dibuat di rumah. Siswa juga terbangkitkan motivasi untuk melukis karena merasa tidak mendapat beban tugas yang berat. Tabel berikut menunjukkan perilaku siswa dalam belajar selama siklus penelitian.

Tabel 5. Persentase Keaktifan Siswa Selama Pelaksanaan Tindakan

\begin{tabular}{|c|c|c|c|c|}
\hline No & Indikator & Siklus I & Siklus II & Siklus II \\
\hline 1 . & $\begin{array}{l}\text { Siswa sangat aktif menulis tiap } \\
\text { kegiatan } \\
\text { Siswa aktif menulis tiap kegiatan } \\
\text { Siswa kurang aktif menulis } \\
\text { Siswa nasif }\end{array}$ & $\begin{array}{l}2(8 \%) \\
9(36 \%) \\
8(32 \%) \\
6(24 \%) \\
\end{array}$ & $\begin{array}{l}3(24 \%) \\
12(48 \%) \\
4(16 \%) \\
3(12 \%) \\
\end{array}$ & $\begin{array}{c}8(32 \%) \\
14(66 \%) \\
3(12 \%) \\
-\end{array}$ \\
\hline & Jumlah & $25(100 \%)$ & $25(100 \%)$ & $25(100 \%)$ \\
\hline
\end{tabular}

Dari tabel di atas terlihat terjadi peningkatan aktivitas siswa selama pelaksanaan tindakan. Pada siklus I masih banyak siswa yang belum atau kurang aktif untuk menilis. Namun, pada siklus II dan III jumlah siswa yang aktif dan sangat aktif menulis terus meningkat. Bahkan, pada akhir siklus III tidak terlihat siswa yang pasif atau tidak menulis jurnalnya.

Peningkatan tersebut dapat tercapai karena bimbingan Guru yang diberikan secara dinamis dan tidak prosedural. Sekalipun menulis jurnal bersifat menulis informai. tetapi bimbingan tetap diberikan sehingga dapat 
menggali ide-ide kreatif siswa dalam menentukan topik dan mengemukakan gagasan. Guru jug berupaya mengaitkan kegiatan menulis jurnal tersehut dengan konteks kehidupan atau materi pembelaiaran sehingga gagasan yang ditulis dapat merefleksikan perkembangan hasil belajar dan perkembangan pribadi siswa. Selain itu, respon tertulis vang' diberikan yang ternyata mampu meningkatkan motivasi untuk menulis. Motivasi itu tumbuh karena siswa merasa guru menghargai dan peduli dengan apa vang ditulisnya.

Pada awal pembiasaan menulis jurnal, siswa banyak membutuhkan waktu untuk menghasilkan sebuah paragraf. tetapi setelah beberapa kali menulis siswa menjadi semakin terampil. Bahkan dalam perkembangannya siswa mau membuat buram tulisannya di rumah, meskipun guru tidak menugaskan ha1 itu. Dampaknya, pemberian waktu sepuluh sampai lima beias menit yang awalnya terkesan mengurangi waktu pembelajaran pokok dapat dimanfaatkan secara efektif, menjadi berharga, dan lebih bermakna dalam upaya melatih keterampilan menulis siswa.

Dampak positif lain yang ditemukan dari pembiasaan menulis jurnal adalah tumbuhnya kemauan dan keterbukaan siswa untuk mengkomunikasikan atau mengekspresikan secara tertulis berbagai masalah atau peristiwa yang dialami. Selain itu, kehbngungan siswa menentukan topik atau kalimat pertama saat mulai menulis dapat teratasi melalui pembiasaan menulis jurnal.

\section{SIMPULAN}

Penerapan kegiatan menuiis jurnai ini dapat memberikan kesempatan lebih banyak kepada siswa untuk mengekspresikan gagasan secara tertulis. Dengan terbiasa dan lebih sering menulis, kualitas paragraf-paragraf yang dihasilkan dapat semakin baik. Dengan, terbiasa menulis kreativitas siswa dalam menulis pun meningkat. Siswa semakin mudah dan terbiasa menemukan berbagai bahan atau gagasan yang dapat ditulisnya.

Penerapan autentik oleh siswa maupun guru dengan memanfaatkan hasil tulisan jurnal siswa juga dapat memberi pengaruh yang besar terhadap peningkatan keterampilan menulis paragraf siswa. Dengan menilai hasil tulisannya sendiri maupun hasil tulisan teman; siswa dapat mengkonstruksi dan menemukan sendiri pengetahuannya Siswa belajar dari berbagai kesalahan untuk menulis lebih baik. Di Sisi lain guru juga dapat memanfaatkan hasil autentik tulisan dalam jurnal siswa sebagai sumber informasi untuk melibat perkembangan belajar siswa. Dalam pelaksanaannya. kegiatan menulis jurnal dan penilaian autentik tersebut dilakukan secara terpadu dan terintegrasi dengan kegiatan pokok pembelajaran bahasa lndonesia

\section{SARAN}

Berdasarkan pembahasan hasil penelitian, penulis mengemukakan saran-saran berikut :

1) Bagi guru bahasa Indonesia maupun guru mata pelajaran lain disarankan kegiatan menulis jurnal ini dapat terus diterapkan dan diintegrasikan dalam pembeiajaran karena selain memberikan gambaran tentang perkembangan keterampilan menulis jurnal juga memberikan gambaran tentang berbagai persoalan yang berkaitan dengan hasil belajar dan perkembangan psikologi siswa.

2) Bagi peneliti selanjutnya yang ingin melakukan penelitian tindakan serupa disarankan untuk melakukannya dalam konteks tataran program studi atau mata pelajaran lain karena menulis rnerupakan proses kognitif dan afektif yang mencakup berbagai bidang.

\section{DAFTAR RUJUKAN}

(http://www/eduplace.com/rdg/r es/litass/, diakses 28 Desember 2002).

Capacchione. L. 1989. The Creative Journal For Children: A Guide for Parents, Teacher, and Counselors. Boston: Shambala.

Depdikbud. 1999. Penelitian Tindakan (Action Research). Bahan Pelatihan Jakarta: Dikdasmen Depdikbud. 
Depdiknas. 2003. Kurikulum 2004. Standar Kompetensi Mata Pelajaran Bahasa dan Sastra Indonesia SMP dan MTs (Draf Final). Jakarta: Depdiknas.

Eanes, R. 1997. Content Area Literacy: Teaching Today's and Tomorrow. New York: Delmar Publisher.

Elliot, J. 1991. AN. Action Reseach for Educational Change. Buckingham: Open University Press.

Federikson, J. \& Collins, A. 2002. What is Authentic Assesment: Term and Condition of Use. Hougton Mifflin Company (online),

Hammond, L.D. dan Snyde, J.D.2001. Authentic Assesment of Reaching Indonesia Context, U.S. Departemen Education (online), (http:www.Contextual.org/abs2. htm., diakses 29 Oktober 2001 oleh Darmono).

Laonhardt, M.2001.99 Cara Menjadikan Anak Anda Bergairah Menulis. Terjemahan oleh Eva Y. Nukman. 2001. Bandung Kaifa.

Nurhadi \& Senduk, A.G. 2003. Pembelajaran Kontekstual dan Penerapannya dalam KBK. Malang: Penerbit Universitas Negeri Malang.

O’Malley, J.M. \& Piece, L.V. 1996. Authentic Assessment for Ennglish Language Learners: Practical Approaches For Teachers. Virginia: Addison-Wesley.

Puhl, C. 1997. Develop, Not Judge: Continuous Assesment in the ESL Classroom. English Teaching Forum, April 1997, pp 2-9.

Saukah, A. 1999. Prinsip Dasar Penilaian Pendidikan Bahasa. Bahasa dan Seni. Tahun 27, Nomor 1, Pebruari 1999, Hal; 19- 33.
Saukah, Ali. 2001. The Teaching Writing and Grammar. Bahasa dan Seni. Tahun 28, Nomor 2, Agustus 2000, Hal. 191-199.

Suparno, 2001. Pembelajaran Bahasa Indonesia dengan Pendekatan Kontekstual. Makalah disajikan pada Simposium di Wisma Jaya, Bogor. Direktorat SLTP, Dirjen Dikdasmen. November, 2001.

Suyanto, K.E. 2002. Authentic Assesment (Penilaian Otentik) dalam Pembelajaran Bahasa. Materi Pelatihan Calon Pelatih Pembelajaran Kontekstual Mata Pelajaran Bahasa Inggris Guru SLT di Malang. Direktorat SLTP, Depdiknas. 2002.

Tompkins, G.E \& Hoskisson, K. 1991. Language Arts : Content and Teaching Strategis. New York: Macmillan.

Tompskin, G.E. 1994. Teaching Writing Balancing Process and Product. New York: Macmillan. 